\title{
ANALISIS DEBIT BANJIR SUNGAI MELUPO DENGAN METODE HSS GAMA 1
}

\author{
Disusun Oleh : \\ TALIB W. KASIM \\ Mahasiswa Teknik Sipil \\ STITEK Bina Taruna Gorontalo \\ Indonesia \\ bukustitek@yahoo.com
}

\begin{abstract}
ABSTRAK
Sungai Meluopo merupakan daerah pasir dan batuan kecil, dibagian hulu sungai merupakan daerah hutan yang saat ini sudah menjadi lahan perkebunan dan pertanian. Mengurangi resiko terjadinya kerusakan akibat banjir di sekitar Sungai Meluopo dibutuhkan upaya pengendalian banjir. Tujuan dalam penelitian ini Menganalisis debit banjir Sungai Meluopo dengan metode HSS Gama I dan pengendalian banjir yang terjadi di Sungai Meluopo. Analisis data terdiri atas analisa curah hujan untuk mendapatkan curah hujan rencana dan analisa debit banjir untuk mendapatkan debit banjir rencana dengan berbagai periode kala ulang. Hasil penelitian menunjukkan bahwa Periode ulang 2 tahun sebesar $Q=93.43 \mathrm{~m}^{3} / \mathrm{det}$, periode ulang 5 tahun sebesar $\mathrm{Q}=105.74 \mathrm{~m}^{3} / \mathrm{det}$, periode ulang 10 tahun sebesar $\mathrm{Q}=112.18 \mathrm{~m}^{3} / \mathrm{det}$, periode ulang 25 tahun sebesar $\mathrm{Q}=120.39 \mathrm{~m}^{3} / \mathrm{det}$, periode ulang 50 tahun sebesar $\mathrm{Q}=123.47 \mathrm{~m}^{3} /$ det, periode ulang 100 tahun sebesar $\mathrm{Q}=127.57 \mathrm{~m}^{3} / \mathrm{det}$.
\end{abstract}

Kata Kunci: Sungai Meluopo, banjir, curah hujan \& debit

\section{PENDAHULUAN}

Daerah Alirah Sungai (DAS Danau Limboto, secara geografis terletak pada $122^{\circ}$ $42^{\prime} 0.24$ " $-123^{\circ} 03^{\prime} 1.17^{\prime \prime}$ BT dan $00^{\circ} 30^{\prime}$ $2.035 "-00^{\circ} 47^{\prime} 0.49 "$ LU sedangkan secara administratif berada di wilayah Kabupaten Gorontalo, Provinsi Gorontalo.

Sungai Meluopo merupakan daerah pasir dan batuan kecil, dibagian hulu sungai merupakan daerah hutan yang saat ini sudah menjadi lahan perkebunan dan pertanian. Hal ini menjadi faktor penyebab banjir, karena hujan yang turun dipermukaan sebagian besar mengalir masuk ke Sungai dengan cepat dan di bagian hilir terjadi penyempitan bibir Sungai sehingga volume air melebihi daya tampung, pada akhirnya air meluap keluar Sungai. Penyempitan yang terjadi pada Sungai Meluopo diakibatkan adanya sedimentasi yang terbawa aliran, dampak dari banjir ini menyebabkan kerugian dibeberapa desa terutama bagian hilir sungai yang diantaranya menggenangi akses-akses jalan dan rumahrumah masyarakat yang berada di sekitar aliran sungai tersebut, rusaknya pemukiman, rusaknya lahan persawahan, disamping itu juga sungai tersebut mengalami kerusakan dengan rusaknya tanggul dan bronjong, check dam yang telah ada sebelumnya 
Mengurangi resiko terjadinya kerusakan akibat banjir di sekitar Sungai Meluopo dibutuhkan upaya pengendalian banjir. Perencanaan pengendalian banjir di suatu DAS dapat dilakukan dengan baik apabila debit banjir rencana diketahui. Sebagai tindak lanjut dari hal ini maka diadakan kajian dan analisa debit banjir dengan judul: "Analisis

Debit Banjir Sungai Meluopo Dengan Metode HSS GAMA I".

\section{RUMUSAN MASALAH}

Berdasarkan identifikasi masalah di atas, yang menjadi rumusan masalah adalah :

1. Berapa debit banjir yang terjadi di Sungai Meluopo ?

2. Bagaimana mengendalikan banjir yang terjadi di Sungai Meluopo?

\section{TUJUAN PENELITIAN}

1. Menganalisis debit banjir Sungai Meluopo dengan metode HSS Gama I.

2. Analisis pengendalian banjir yang terjadi di Sungai Meluopo.

\section{BATASAN MASALAH}

Ruang lingkup pembahasan tugas akhir ini adalah :

1. Data hujan yang diambil adalah dari Stasiun Alo, Stasiun Pohu, Stasiun Biyonga.

2. Kala ulang rencana dibatasi pada $2,5,10$, 25, 50, 100 tahun.

\section{MANFAAT PENELITIAN}

Manfaat Penelitian dalam pembahasan tugas akhir ini adalah :

\section{a. Teoritis}

Memberikan informasi tentang debit banjir yang terjadi pada setiap tahun, dimana estimasi besarnya debit tersebut secara hidrologi kemungkinannya akan terulang kembali pada periode - periode mendatang.

Sebagai bahan informasi dan pertimbangan bagi pemerintah daerah dalam merencanakan penanggulangan masalah banjir di Sungai Meluopo.

\section{b. Praktis}

Hasil dari analisa debit banjir digunakan sebagai masukan penting dalam merencanakan struktur bangunan penanggulangan banjir.

Normalisasi Sungai dapat dilakukan apabila besar debit yang terjadi pada Sungai Meluopo melebihi daya tampung.

\section{LANDASAN TEORI}

\section{Daur hidrologi}

Daur hidrologi merupakan proses kontinyu dimana air bergerak dari bumi ke atmosfer dan kemudian kembali lagi ke bumi. Air di permukaan tanah dan laut menguap ke udara. Uap air tersebut bergerak dan naik ke atmosfer, yang kemudian mengalami kondensasi dan berubah menjadi titik-titik air yang berbentuk awan. Selanjutnya titik-titik air tersebut jatuh sebagai hujan ke permukaan laut dan daratan. Hujan yang jatuh sebagian tertahan oleh tumbuh-tumbuhan (intersepsi) dan selebihnya sampai ke permukaan tanah. Sebagian air hujan yang sampai ke permukaan tanah akan meresap ke dalam tanah (infiltrasi) dan sebagian lainnya mengalir di atas permukaan tanah (aliran permukaan atau surface run off) mengisi cekungan tanah, 
danau, dan masuk ke sungai dan akhirnya mengalir ke laut. Air yang meresap ke dalam tanah sebagian mengalir di dalam tanah (perkolasi) mengisi airtanah yang kemudian keluar sebagai mata air atau mengalir ke sungai. Akhirnya aliran air di sungai akan sampai ke laut. Proses tersebut berlangsung terus menerus yang disebut dengan siklus hidrologi.

\section{Daerah Aliran Sungai}

Sungai merupakan jaringan alur-alur pada permukaan bumi yang terbentuk secara alamiah, mulai dari bentuk kecil di bagian hulu sampai besar di bagian hilir. Air hujan yang jatuh di atas permukaan bumi dalam perjalanannya sebagian kecil menguap dan sebagian besar mengalir dalam bentuk alir-alir kecil, kemudian menjadi alur-alur sedang seterusnya berkumpul menjadi satu alur besar atau utama. Dengan demikian dapat dikatakan sungai berfungsi menampung curah hujan dan mengalirkannya ke laut. (Asdak Chay, 2002)

\section{Curah Hujan Rencana}

Data curah hujan yang digunakan untuk perhitungan debit banjir adalah hujan yang terjadi pada daerah aliran sungai pada waktu yang sama. Curah hujan yang diperlukan untuk penyusunan suatu rancangan pemanfaatan air dan rancangan pengendalian banjir adalah curah hujan rata-rata di seluruh daerah yang bersangkutan, bukan curah hujan pada suatu titik tertentu. Curah hujan ini disebut curah hujan area dan dinyatakan dalam mm (Sosrodarsono, 2003).

\section{Parameter Statistik}

Parameter statistik yang digunakan dalam analisis data hidrologi yaitu: rata-rata hitung, simpangan baku (standar deviasi), koefisien variasi, kemencengan (koefisien skewness) dan koefisien kurtosis

\section{Rata rata Hitung}

Rata-rata hitung merupakan nilai rata-rata dari sekumpulan data

$$
\bar{X}=\frac{1}{n} \sum_{i=1}^{n} X_{i}
$$

\section{Simpang Baku}

Apabila penyebaran data sangat besar terhadap nilai rata-rata maka nilai $\mathrm{S}$ akan besar, tetapi apabila penyebaran data sangat kecil terhadap nilai rata-rata maka $\mathrm{S}$ akan kecil.

$$
S=\sqrt{\frac{\sum_{i=1}^{n}\left(X_{i}-\bar{X}\right)^{2}}{n-1}}
$$

\section{Koefisien Skewness (Kemencengan)}

Kemencengan (skewness) adalah suatu nilai yang menunjukkan derajat ketidaksimetrisan dari suatu bentuk distribusi. Pengukuran kemencengan adalah mengukur seberapa besar suatu kurva frekuensi dari suatu distribusi tidak simetris atau menceng.

$$
C s=\frac{n}{(n-1)(n-2) \cdot S^{3}} \sum_{i=1}^{n}\left(X_{i}-\bar{X}\right)^{3}
$$

\section{Koefisien Variasi}

Koefisien variasi adalah nilai perbandingan antara deviasi standard dengan nilai rata-rata hitung dari suatu distribusi. 


$$
C v=\frac{S}{\bar{X}}
$$

\section{Koefisien Kurtosis}

Pengukuran kurtosis dimaksudkan untuk mengukur kemencengan dari bentuk kurva distribusi, yang umumnya dibandingkan dengan distribusi normal. Koefisien kurtosis digunakan untuk menentukan keruncingan kurva distribusi, dan dapat dirumuskan sebagai berikut :

$$
C k=\frac{n^{2}}{(n-1)(n-2)(n-3) S^{4}} \sum_{i=1}^{n}\left(X_{i}-\bar{X}\right)^{4}
$$

\section{Kriteria pemilihan awal tipe distibusi berdasarkan parameter statistic}

Parameter-parameter

yang

digunakan sebagai langkah awal penentuan tipe distribusi adalah $\mathrm{Cs}, \mathrm{Cv}, \mathrm{Ck}$. Kriteria pemilihan untuk tiap tipe distribusi berdasarkan parameter statistik adalah sebagai berikut :

\section{Tipe distribusi Normal}

$$
C s \approx 0 ; C k \approx 3
$$

\section{Tipe disribusi Log Normal}

$$
C s \approx 3 \mathrm{Cv}
$$

\section{Tipe distribusi Gumbel}

$$
C s \approx 1,139 ; C k \approx 5,4
$$

\section{Distribusi peluang}

Fungsi distribusi peluang yang dipergunakan dalam penulisan ini adalah : Distribusi Normal, Distribusi Log-Normal, Distribusi Gumbel, Distribusi Pearson III, Distribusi Log Pearson III. (Soewarno, 1995)

$$
X=\bar{X}+k \cdot S
$$

\section{Distribusi Log Normal}

$\log X=\overline{\log X}+k \cdot S_{\log }$

\section{Distribusi Gumbel}

$$
X=\bar{X}+\frac{S}{S n}(Y-Y n)
$$

\section{Distribusi Log Pearson Tipe III}

$$
\log X=\overline{\log X}+k \cdot S \log X
$$

\section{Hidrograf satuan sintetik (HSS) GAMA I}

Salah satu cara untuk menghitung debit banjir rencana di DASdengan ketersediaan data yang minim Snyder memanfaatkan parameter DAS untuk memperoleh Hidrograf Satuan Sintetik. Dengan demikian, langkah awal yang sangat penting dalam pemakaian HSS GAMA I adalah pengenalan cara penetapan tingkat sungai, yang mengikuti cara Strahler (Chow, 1989) yang dapat dilihat pada gambar. Untuk dapat mengetahui system sungai yang berada dalam suatu DAS, maka harus digunakan peta topografi, dengan skala $1: 50.000$

\section{Hidrograf Satuan Sintetis (HSS) Gama I}

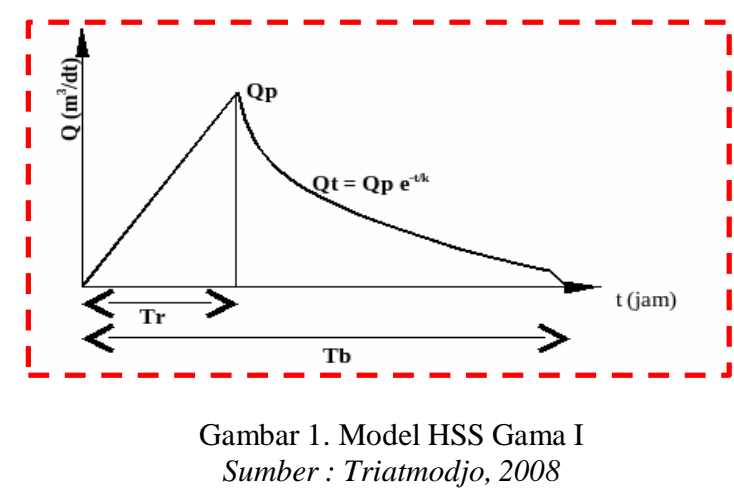


Parameter yang diperlukan dalam analisis

menggunakan HSS Gama I antara lain:

- Luas DAS (A)

- Panjang alur sungai utama (L)

- Panjang alur sungai ke titik berat DAS

Kelandaian / slope sungai (s)

- Kerapatan jaringan kuras (D)

Selain parameter diatas, masih ada parameter lain yang dipakai, antara lain:

- Faktor sumber (SF)

- Frekuensi sumber (SN)

- Luas DAS sebelah hulu (RUA)

- Faktor simetri (SIM)

- Jumlah pertemuan sungai (JN)

\section{Waktu Naik (TR)}

Waktu naik (TR) adalah waktu yang diukur dari saat hidrograf mulai naik sampai waktu terjadinya debit puncak

$T R=0.43\left(\frac{L}{100 S F}\right)^{3}+1.0665$ SIM +1.2775

\section{Debit Puncak (QP)}

Debit puncak adalah debit maksimum yang terjadi dalam suatu kasusu tertentu

$$
Q P=0.1836 A^{0.5886} T R^{-0.4008} J N^{0.2381}
$$

\section{Waktu Dasar (TB)}

Waktu dasar adalah waktu yang diukur dari saat hidrograf mulai naik sampai waktu dimana debit kembali pada suatu besaran yang ditetapkan.

$$
T B=27.4132 T R^{0.1457} s^{-0.0986} S N^{0.7344} R U A^{0.2574}
$$

RADIAL - juRnal perADaban saIns, rekayAsa dan teknoLogi Sekolah Tinggi Teknik (STITEK) Bina Taruna Gorontalo VOLUME 7 NO. 2 Desember 2019

$K=0.5617 A^{0.1798} s^{-0.1446} S F^{-1.0897} D^{0.0452}$

\author{
Aliran Dasar (QB) \\ $Q B=0.4751 A^{0.6444} D^{0.9430}$
}

\section{METODE PENELITIAN}

\section{Survey Untuk Mendapatkan Data \\ Sekunder}

Survey ini untuk mendapatkan data-data sekunder yang mendukung data-data primer, seperti:

a) Peta Hidrologi DAS Limboto

b) Data Curah Hujan yang didapatkan dari Balai Wilayah Sungai Sulawesi II Propinsi Gorontalo, dan curah hujan mencakup tiga stasiun yang ada di sekitar DAS Limboto yaitu Stasiun Alo (Ds. Datahu), Stasium Pohu (Ds. Pilolalenga), dan Stasiun Biyonga (Ds. Biyonga).

c) Data debit air sungai Meluopo.

\section{TAHAPAN PENELITIAN}

Berdasarkan studi kasus melalui survey atau pengamatan langsung di lapangan yang disertai dengan analisis berdasarkan metodemetode dan formula yang tersedia.

Analisis data terdiri atas :

1. Analisa curah hujan

Analisa ini dilakukan untuk mendapatkan curah hujan rencana

2. Analisa debit banjir

Analisa ini dilakukan untuk mendapatkan debit banjir rencana dengan berbagai periode kala ulang

\section{Koefisien Tampungan}




\section{HASIL PENELITIAN DAN}

\section{PEMBAHASAN ANALISIS CURAH \\ HUJAN RENCANA}

Data curah hujan harian maksimum yang digunakan dalam analisa ini bersumber dari periode pencatatan tahun 2003 s/d 2014. Dipilih pos hujan yang berada di sekitar DAS Limboto, yaitu Stasiun Alo, Stasiun Pohu, dan Stasiun Biyonga. Datanya dapat dilihat pada Tabel 4.2 berikut ini.

\section{Curah Hujan Rata Rata}

Tabel 4.2 Curah hujan rata-rata dengan cara Rata-rata Aljabar

\begin{tabular}{c|c|c|c|c|}
\hline \multirow{2}{*}{ Tahun } & \multicolumn{2}{|c|}{ Curah Hujan Harian Maksimum (mm) } & \multirow{2}{*}{$\begin{array}{c}\text { Curah hujan } \\
\text { rata-rata (mm) }\end{array}$} \\
\cline { 2 - 4 } & Sta. Alo & Sta. Pohu & Sta.Biyonga & 47.33 \\
\hline 2003 & 43.16 & 46.53 & 52.30 & 34.60 \\
\hline 2004 & 32.66 & 22.38 & 48.75 & 30.87 \\
\hline 2005 & 27.79 & 24.06 & 40.75 & 39.92 \\
\hline 2006 & 36.20 & 47.91 & 35.66 & 44.89 \\
\hline 2007 & 39.41 & 40.10 & 55.16 & 43.75 \\
\hline 2008 & 36.29 & 42.52 & 52.43 & 31.02 \\
\hline 2009 & 18.20 & 39.11 & 35.75 & 53.42 \\
\hline 2010 & 51.75 & 53.93 & 54.57 & 35.91 \\
\hline 2011 & 31.15 & 42.72 & 33.87 & 45.96 \\
\hline 2012 & 43.67 & 37.29 & 56.92 & 43.21 \\
\hline 2013 & 36.75 & 47.88 & 45.01 & 35.43 \\
\hline 2014 & 33.18 & 31.81 & 41.29 & \\
\hline iwmberi hasil analisis & & &
\end{tabular}

Dari hasil analisis perhitungan hujan rata-rata di atas, diperoleh cural ujjan rata-rata maksimum terjadi pada tahun 2010 sebesar $53.42 \mathrm{~mm}$.

\section{Analisis Distribusi Peluang}

Analisis hidrologi terhadap data curah hujan dilakukan untuk menetapkan besar curah hujan yang mungkin terjadi pada kala ulang tertentu. Akurasi hasil analisis tergantung seberapa besar suatu kurva frekuensi peluang tipe distribusi tertentu dapat mewakili suatu distribusi data pengamatan. Dalam penulisan ini, tipe distribusi yang akan digunakan adalah
RADIAL - juRnal perADaban saIns, rekayAsa dan teknoLogi Sekolah Tinggi Teknik (STITEK) Bina Taruna Gorontalo VOLUME 7 NO. 2 Desember 2019

distribusi Normal, log Normal, Gumbel, Pearson III dan log Pearson III

\begin{tabular}{|c|c|c|c|c|}
\hline No & $\begin{array}{c}\text { Tipe } \\
\text { distribusi }\end{array}$ & $\begin{array}{c}\text { Syarat } \\
\text { parameter } \\
\text { statistik }\end{array}$ & $\begin{array}{c}\text { Parameter statistik data } \\
\text { pengamatan }\end{array}$ & Keterangan \\
\hline \multirow[b]{2}{*}{1} & \multirow{2}{*}{ Normal } & $\mathrm{Cs} \approx 0$ & $\mathrm{Cs} \approx 0.174$ & \multirow{2}{*}{ memenuhi } \\
\hline & & $\mathrm{Ck} \approx 3$ & $\mathrm{Ck} \approx 2.985$ & \\
\hline \multirow[b]{2}{*}{2} & \multirow{2}{*}{$\begin{array}{c}\text { Log } \\
\text { Normal }\end{array}$} & \multirow[b]{2}{*}{$\mathrm{Cslog} \approx 3 \mathrm{Cv}$} & Cslog $\approx-0.094$ & \multirow{2}{*}{$\begin{array}{c}\text { Tidak } \\
\text { memenuhi }\end{array}$} \\
\hline & & & $\mathrm{Cv} \approx 0.048$ & \\
\hline \multirow[b]{2}{*}{3} & \multirow{2}{*}{ Gumbel } & $\mathrm{Cs} \approx 1,139$ & $\mathrm{Cs} \approx 0.174$ & \multirow{2}{*}{$\begin{array}{c}\text { Tidak } \\
\text { memenuhi }\end{array}$} \\
\hline & & $\mathrm{Ck} \approx 5,4$ & $\mathrm{Ck} \approx 2.985$ & \\
\hline
\end{tabular}

Berdasarkan hasil tinjauan parameterparameter statistik data pengamatan terhadap syarat batas parameter statistik parameter distribusi di atas dapat disimpulkan bahwa tipe distribusi peluang yang mungkin sesuai adalah tipe distribusi Normal

\section{ANALISA DEBIT BANJIR RENCANA}

Untuk menghitung debit banjir rencana digunakan metode Hidrograf Satuan Sintetik (HSS) GAMA I yang dikembangkan oleh Sri Harto (1985). Hidrograf Satuan Sintetik (HSS) GAMA I ini cocok untuk digunakan dalam menghitung debit banjir di seluruh DAS yang ada di Indonesia terutama pada lokasi Sungai Meluopo yang memiliki daerah tofografi berbukit dan kemiringan lereng yang curam

\section{HSS Gama I}

Untuk menghitung debit banjir rencana dengan menggunakan Hidrograf Satuan Sintetik (HSS) GAMA I, perlu diketahui parameter-parameter DAS yang merupakan hasil analisis dari peta topografi dengan skala 1: 50000. 
a. Faktor Sumber (SF)

$S F=0.528$

b. Frekuensi Sumber (SN)

$S N=0.517$

c. Faktor Lebar (WF)

Lebar DAS di hulu $\left(\mathrm{W}_{\mathrm{U}}\right) \quad=2.01 \mathrm{~km}$

Lebar DAS di hilir $\left(\mathrm{W}_{\mathrm{L}}\right) \quad=2.44 \mathrm{~km}$

$W F=0.82 \mathrm{~km}$

d. Luas DAS (A) $=20.45 \mathrm{~km}^{2}$

e. Luas DAS sebelah hulu (RUA)

Luas DAS sebelah hulu $\left(\mathrm{A}_{\mathrm{U}}\right) \quad=$

$9.68 \mathrm{~km}^{2}$

$R U A=0.47$

f. Faktor Simetri (SIM)

$S I M=0.390$

g. Panjang Sungai Utama (L) $=13.84 \mathrm{~km}$

h. Slope Sungai Utama (s)

ketinggian sungai di hulu $=3.84 \mathrm{~m}$

ketinggian sungai di hilir $\quad=6.32 \mathrm{~m}$

$s=0.00020$

i. Kerapatan Jaringan Kuras (D)

$D=2.902$

j. Jumlah Percabangan Sungai (JN)

$J N=60-1=59$

Setelah parameter-parameter DAS diketahui, selanjutnya dapat dihitung variabel-variabel pokok dalam Hidrograf Satuan Sintetik (HSS)

GAMA I sebagai berikut :

1. Waktu Naik (TR)

nilai $\mathrm{TR}=1.69 \mathrm{jam}$

2. Debit Puncak $(\mathrm{QP}$

Diperoleh nilai $\mathrm{QP}=2.32 \mathrm{~m}^{3} / \mathrm{det}$

3. Waktu Dasar (TB)

Diperoleh nilai $\mathrm{TB}=34.41 \mathrm{jam}$

4. Koefisien Tampungan

Diperoleh nilai $\mathrm{K}=6.84$
5. Aliran Dasar (QB)

$Q B=9.07 \mathrm{~m}^{3} / \mathrm{det}$

6. Hidrograf Debit (Qt)

$Q t=Q p \cdot \operatorname{Exp}^{-((t-T R) / K)}($ setelah TR $=1.69 \mathrm{jam})$

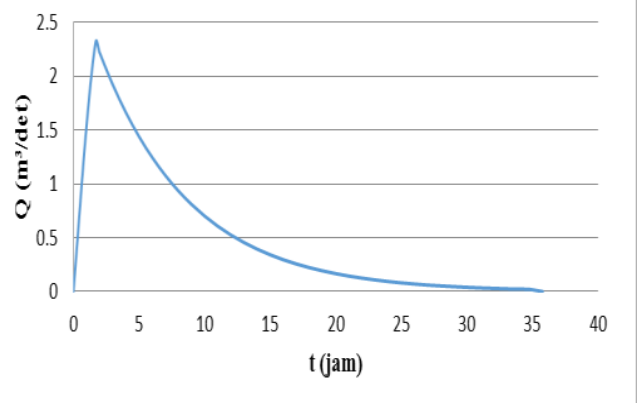

Gambar 4.1. Hidrograf Satuan Sintetis Gama I

Dari Gambar di atas, dapat disimpulkan bahwa hidrograf debit (Qt) terbesar atau Qt Puncak jatuh pada waktu ke- 1,69 jam. Mulai dari waktu 0-1.69 jam, Hidrograf debit terus meningkat dan mencapai Hidrograf Debit Puncak sebesar $2.32 \mathrm{~m}^{3} /$ det. Setelah waktu naik (TR) 1,69 jam hidrograf debit mulai menurun dan menjadi nol kembali pada waktu 35,81 jam.

\section{HUJAN JAM-JAMAN}

Setelah mengetahui variabel-variabel pokok dalam HSS GAMA I, maka untuk menggambar lengkung hidrograf banjir digunakan persamaan Van Damm, tapi sebelumnya diperlukan hujan jam-jaman yang diubah dari hujan harian. Dengan menganggap distribusi hujan jam-jaman diambil dari hasil kajian yang telah dilakukan oleh Fakultas Teknik Universitas Gadjah Mada pada tahun 1986, yaitu hujan terjadi dalam 4 jam sebagai berikut : 
Tabel 4. 12. Distribusi hujan jam-jaman untuk hujan yang terjadi selama 4

\begin{tabular}{|c|c|c|c|} 
jam \\
\begin{tabular}{|c|c|c|c|c|}
\hline Jam ke- & 1 & 2 & 3 & 4 \\
\hline Besar Hujan (\%)(r) & 12.5 & 52.5 & 18 & 17 \\
\hline Sumber : Darmanto, 9990
\end{tabular}
\end{tabular}

Perhitungan distribusi hujan jam-jaman untuk hujan yang terjadi selama 4 jam untuk curah hujan dalam berbagai periode ulang selanjutnya dibuat dalam Tabel 4.13 berikut ini.

\begin{tabular}{|c|c|c|c|c|c|}
\hline \multirow{3}{*}{$\begin{array}{c}\text { Tabel } \\
\text { Kala ulang } \\
\text { (tahun) }\end{array}$} & 13. Distri & i hujan ja & jaman & k berb & ode \\
\hline & \multirow{2}{*}{$\mathrm{R} 24(\mathrm{~mm})$} & \multicolumn{4}{|c|}{ Distribusi Hujan Jam-jaman (mm) } \\
\hline & & Jam ke-1 & Jam ke-2 & Jam ke-3 & Jam ke-4 \\
\hline 2 & 40.53 & 5.066 & 21.276 & 7.295 & 6.889 \\
\hline 5 & 46.44 & 5.805 & 24.380 & 8.359 & 7.895 \\
\hline 10 & 49.54 & 6.192 & 26.006 & 8.916 & 8.421 \\
\hline 25 & 53.48 & 6.685 & 28.076 & 9.626 & 9.091 \\
\hline 50 & 54.96 & 6.870 & 28.852 & 9.892 & 9.343 \\
\hline 100 & 56.93 & 7.116 & 29.887 & 10.247 & 9.678 \\
\hline
\end{tabular}

Untuk Distribusi hujan jam-jaman berbagai periode ulang di atas, dapat disimpulkan bahwa hujan terbesar semuanya terjadi pada jam ke-2 untuk semua kala ulang. Hujan mulai naik dari jam pertama kemudian mencapai puncak pada jam ke-2 dan mulai menurun pada jam ke-3 dan jam ke-4

\section{Hidrograf banjir}

Tabel Hidrograf banjir untuk periode ulang 2,5,10,25,50,100 tahun dapat dilihat pada Lampiran A. Hasil perhitungan Debit Banjir rencana dengan metode HSS GAMA I dengan berbagai periode ulang Dapat dilihat pada Tabel 4.14 bawah ini.

Tabel 4.14. Debit banjir rencana untuk berbagai periode ulang
\begin{tabular}{|c|c|}
\hline $\begin{array}{c}\text { Periode Ulang } \\
\text { (tahun) }\end{array}$ & $\begin{array}{c}\text { Debit Banjir Rencana } \\
\left.\text { ( } \mathrm{m}^{3} / \mathrm{det}\right)\end{array}$ \\
\hline 2 & 93.43 \\
\hline 5 & 105.74 \\
\hline 10 & 112.18 \\
\hline 25 & 120.39 \\
\hline 50 & 123.47 \\
\hline 100 & 127.57 \\
\hline
\end{tabular}

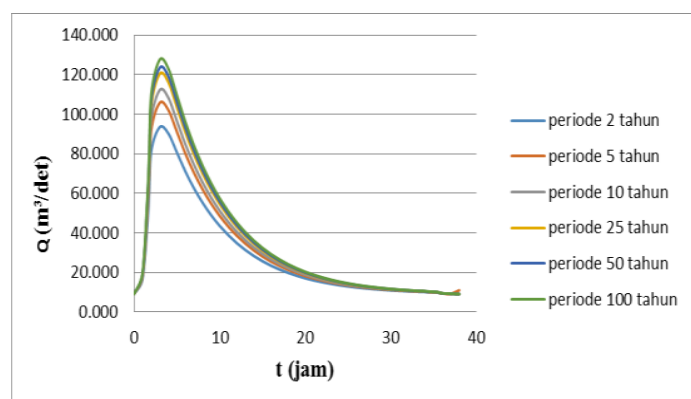

Gambar 4.14. Hidrograf debit banjir rencana dengan berbagai periode ulang

Dari Tabel dan Gambar di atas dapat disimpulkan bahwa besarnya Debit banjir rencana Sungai Meluopo dengan berbagai periode ulang adalah periode ulang 2 tahun sebesar $Q_{=} 93.43 \mathrm{~m}^{3} / \mathrm{det}$, periode ulang 5 tahun sebesar $\mathrm{Q}=105.74 \mathrm{~m}^{3} / \mathrm{det}$, periode ulang 10 tahun sebesar $\mathrm{Q}=112.18 \mathrm{~m}^{3} / \mathrm{det}$, periode ulang 25 tahun sebesar $\mathrm{Q}=120.39 \mathrm{~m}^{3} / \mathrm{det}$, periode ulang 50 tahun sebesar $\mathrm{Q}=123.47 \mathrm{~m}^{3} / \mathrm{det}$, periode ulang 100 tahun sebesar $Q=$ $127.57 \mathrm{~m}^{3} /$ det.

\section{ANALISIS PENGENDALIAN BANJIR}

Pengendalian banjir Sungai Meluopo dilakukan untuk mereduksi dan menanggulangi limpasan yang terjadi akibat debit banjir rencana dengan berbagai periode ulang, melalui alternatif upaya struktural, antara lain : pembuatan/ peninggian tanggul banjir dengan menggunakan revetmen, bronjong dialur Sungai dikarenakan kondisi 
bantaran yang sudah sempit dibagian hilir dan kondisi area Sungai yang sudah menjadi bagian dari infrastruktur yang terdiri dari jalan transportasi, permukiman warga, lahan pertanian, dll sehingga tidak dimungkinkan untuk pekerjaan penanggulan menggunakan tanah

\section{KESIMPULAN}

Berdasarkan analisis debit banjir dengan menggunakan metode HSS GAMA 1 Debit banjir Sungai Meluopo dengan berbagai periode ulang adalah sebagai berikut:

Periode ulang 2 tahun sebesar $Q_{=} 93.43$ $\mathrm{m}^{3} /$ det, periode ulang 5 tahun sebesar $\mathrm{Q}=105.74 \mathrm{~m}^{3} / \mathrm{det}$, periode ulang 10 tahun sebesar $\mathrm{Q}=112.18 \mathrm{~m}^{3} / \mathrm{det}$, periode ulang 25 tahun sebesar $\mathrm{Q}=120.39 \mathrm{~m}^{3} / \mathrm{det}$, periode ulang 50 tahun sebesar $\mathrm{Q}=123.47 \mathrm{~m}^{3} /$ det, periode ulang 100 tahun sebesar $\mathrm{Q}=127.57 \mathrm{~m}^{3} /$ det.

\section{SARAN}

Dengan memperhatikan debit banjir rencana yang sangat tinggi dan kapasitas penampang Sungai yang kurang memadai, maka diharapkan bagi pemerintah untuk segera merealisasikan penuntasan pembuatan bangunan pengendalian banjir, serta peningkatan kapasitas alur sungai dengan normalisasi Sungai yang telah menjadi program pemerintah daerah selama ini.

\section{DAFTAR PUSTAKA}

Chay A, 2002, Hidrologi dan Pengelolaan Daerah Aliran Sungai, Gadjah Mada University Press, Yogyakarta.

Chow, 1989, Hidrolika Saluran Terbuka (Open Channel Hydraulics), Erlangga, Jakarta.
Kamiana, I.M , 2011 "Teknik Perhitungan Debit Rencana Bangunan Air", Graha Ilmu, Yogyakarta.

Loebis, dkk, 1993, Hidrologi Sungai, Yayasan Badan Penerbit PU, Jakarta

Soemarto, C.D, 1999, Hidrologi Teknik, Erlangga Jakarta

Soewarno, 1995, Hidrologi Aplikasi Metode Statistik Untuk Analisa Data, Nova, Bandung.

Sosrodarsono, S, 2003, Hidrologi Untuk Pengairan, PT. Pradnya Paramita, Jakarta.

Sri Harto, 1993, Analisa Hidrologi, Gramedia Pustaka Utama, Jakarta.

Suripin, 2004, Sistem Drainase Perkotaan Yang Berkelanjutan, Andi, Yogyakarta

Triatmodjo, B, 2008, Hidrologi Terapan, Beta Offset, Yogyakarta

Wesli, 2008, Drainase Perkotaan, Graha Ilmu, Yogyakarta

Wilson, E, M 1993, Hidrologi Teknik, Edisi ke-4, ITB, Bandung. 